\title{
Tumor Necrosis Factor- $\alpha$, Lactate Dehydrogenase and Gamma Glutamyl Transferase as Independent Predic- tors for Monitoring HCV-Chronic Liver Disease
}

\author{
Hoda Mohamed El-Emshaty ${ }^{1 *}$, Mohy Eldin Abdelfatah Abdel Atty ${ }^{2}$, Yaser Mostafa Elgazar ${ }^{1}$ and \\ Talat Abdallah Ibrahim ${ }^{1}$ \\ ${ }^{1}$ Gastro-Enterology Surgical Center, Faculty of Medicine, Egypt \\ ${ }^{2}$ Chemistry Department, Faculty of Science, Egypt \\ *Corresponding author: Hoda Mohamed El-Emshaty, Gastro-Enterology Surgical Center, Faculty of Medicine, Egypt
}

\section{ARTICLE INFO}

\section{Received: 业 April 15, 2019}

Published: 幽 April 25, 2019

Citation: H M El-Emshaty, M E Abdelfatah Abdel Atty, Yaser Mostafa E, Talat Abdallah I. Tumor Necrosis Factor- $\alpha$, Lactate Dehydrogenase and Gamma Glutamyl Transferase as Independent Predictors for Monitoring HCV-Chronic Liver Disease. Biomed J Sci \& Tech Res 17(3)-2019. BJSTR. MS.ID.003004.

\begin{abstract}
The majority of HCC patients are not amenable to curative therapy as they are detected at late stages. Therefore, this study was conducted to evaluate the clinical implications of TNF- $\alpha$ level and its correlation with the activity of GGT and LDH in monitoring the progression of HCV-chronic liver disease. Forty-eight patients suffering from HCV-chronic liver disease were categorized into $24(50 \%)$ cases with HCC, $14(29.2 \%)$ cases with LC and $10(20.8 \%)$ cases with $\mathrm{CH}$. Twenty-five healthy individuals (HI) served as control group. Sera of all individuals were examined for TNF- $\alpha$, LDH, GGT, AFP and all values were correlated with other laboratory investigations. The results showed that serum levels of TNF- $\alpha$, LDH, AFP were elevated significantly in HCC patients compared to LC and CH but the difference between LC and CH was elevated significantly only $(p<0.0001)$ in TNF- $\alpha$. Significant association was recorded between LDH and TNF- $\alpha$, GGT, AFP, ALT and AST. Linear regression for TNF- $\alpha$, LDH and AFP showed significant prediction in progressive HCV-chronic liver disease. Therefore, LDH and TNF- $\alpha$ could be used as independent predictors for evaluating the progression of chronic inflammation leading to cancer development.
\end{abstract}

Keywords: Tumor necrosis Factor- $\alpha$ (TNF- $\alpha$ ), Lactate Dehydrogenase (LDH), Gamma Glutamyle Transferase (GGT), Alpha Fetoprotein (AFP), HCV-chronic liver diseases

\section{Introduction}

Hepatocellular carcinoma (HCC) ranks as the $5^{\text {th }}$ most common malignant cancer and the $3^{\text {rd }}$ most frequent cause of cancer leading death worldwide [1-3]. HCC is an environmentally related cancer, with both viral and chemical carcinogens involved in multi stage process [4]. However, the reasons for viral persistence and transformation from acute to chronic infection are not clear, but it is known that both viral and host characteristics can influence the outcome of the infection [5]. The host response to hepatitis viruses involves various components of the immune system, including T-lymphocyte immune-regulatory cytokines [6,7]. TNF- $\alpha$, a monocyte/macrophage-derived cytokine, is known to possess antineoplastic, anti-viral, and potent immunomodulatory activities [8]. It has been reported that TNF- $\alpha$ is involved in the pathogenesis of a diversity of liver diseases including viral hepatitis and HCC [9]. The majority of HCC patients are not amenable to curative therapy as they are detected at late stages [4].

Therefore, several tumor markers are used currently for the evaluation of tumor progression and prognosis of patients with HCC including AFP, Lens Culinaris agglutinin A-reactive fraction of AFP (AFP-L3) [10]. However, AFP is a fairly specific but insensitive marker for HCC; therefore, to improve the sensitivity of HCC detection, various markers are used in combination with AFP [11]. GGT is a microsomal enzyme present in hepatocytes and biliary epithelial cells, renal tubules, pancrease and intestine [12]. It is generally accepted as the most sensitive marker of cholestasis and pancreatic disease or enzymatic induction by alcohol and drugs [13]. However, GGT activity is not necessarily considered a routine test in the evaluation of liver disease because it is believed to contribute 
little diagnostic information [14-16]. Lactate dehydrogenase (LDH), which is a key enzyme in the conversion of pyruvate to lactate under anaerobic environment [17], has been recognized as an indirect marker of the extent of tumor hypoxia a key biological mechanism for the development of treatment resistance in cancer cells $[18,19]$. It was known that LDH had 5 isoenzymes, and each of them might function differently in the tumor progression [20]. Therefore, this study was conducted to evaluate the clinical significance of TNF- $\alpha$ level and its correlation with the activity of LDH and GGT in HCVprogressive liver disease.

\section{Materials and Methods}

Forty-eight ( 44 men and 4 women) patients suffering from HCVchronic liver diseases admitted at Gastroenterology surgical center, Mansoura university, Egypt were included in our study. All patients had positive reactivity for HCV Abs with detectable HCV RNA and with no serologic evidence of co-infection with other hepatotropic viruses or human immunodeficiency virus. Twenty-five (15 men and 10 women; mean age $25.3 \pm 4.63$ yrs, range 19 -34 yrs) healthy individuals (HI) served as control group were selected without a clinical history of hepatitis and without symptoms or signs of liver diseases. HCV-infected patients were histopathologically diagnosed and accordingly divided into: $24(50 \%)$ patients with HCC (23 men and 1 women; mean age 56.4 $\pm 6.4 \mathrm{yrs}$; range $50-66 \mathrm{yrs})$; $14(29.2 \%)$ patients with liver cirrhosis (13 men and 1 women; mean age $52.6 \pm 9.14 y r s$, range $30-61 y r s)$ and $10(20.8 \%)$ patients with chronic hepatitis ( 8 men and women; mean age $48.9 \pm 12.4$ yrs; range 26-65yrs). Serum samples of all individuals were collected and stored at $-70^{\circ} \mathrm{C}$ until used. All sera were investigated for ALT, AST, Albumin, T.bilirubin, LDH and GGT using Hitachi 750XRC Analyzer. Serum AFP was detected using AFP kit (Abbott Laboratories, USA) and the results were automatically calculated using $1 \mathrm{Mx}$ Abbott equipment. In vitro human TNF-alpha ELISA kit (RayBiotech, Inc., www.raybiotech.com) was used for the quantitative measurement of serum TNF-alpha.

\section{Statistical Analysis}

Continuous variables were expressed as mean \pm SD and categorical variables were expressed as frequencies and percentages. To calculate the significance between categorical variables; Chi-square test or Fisher's exact test was used and the difference in continuous variables, Kruskal Wallis and MannWhitney U test was used. Linear regression analysis was used for correlation's statistical analysis. Differences between variables were considered significant at $\mathrm{p}<0.05$.

\section{Results}

Demographic and base line characteristics of HCV-chronic liver disease patients and HI were listed in Table 1 . The difference was considered significant between HCC and LC as regard to age ( $p=0.038)$, ALT ( $p=0.003)$, AST ( $p=0.017)$, Alb. $(p=0.004)$ and HCV viral load $(p=0.005)$ but the difference between LC and $\mathrm{CH}$ was detected significant only in ALT ( $p=0.004)$ and T.bilirubin ( $p=0.02)$. All study groups showed highly significant difference $(p<0.0001)$ compared to $\mathrm{HI}$ as regard to all variables. Serum concentrations of AFP, LDH, GGT and TNF- $\alpha$ in all individuals were listed in Table 2. The difference between HCC and LC was recorded in AFP $(p<0.0001)$, LDH $(p=0.001)$, and TNF- $\alpha(p<0.0001)$; between HCC and $\mathrm{CH}$, significant difference was detected in AFP ( $\mathrm{p}=0.003), \mathrm{LDH}$ $(\mathrm{p}=0.008)$ and TNF- $\alpha(\mathrm{p}<0.0001)$. However, LC and CH patients showed significant difference $(\mathrm{p}<0.0001)$ in TNF- $\alpha$ only. Compared to HI, significant difference was recorded with HCC $(p<0.0001)$ in AFP, GGT, LDH, TNF- $\alpha$; with LC in LDH and TNF- $\alpha(p<0.0001)$ and GGT ( $p=0.005)$; with $\mathrm{CH}$, the difference was considered significant in GGT and LDH $(\mathrm{p}<0.0001)$ and in TNF- $\alpha(\mathrm{p}=0.019)$.

Table 1: Demographic and base line characteristics of patients with HCV-chronic liver disease and healthy individuals.

\begin{tabular}{|c|c|c|c|c|}
\hline & HCC & LC & CH & HI\# \\
\hline Age (yrs) & $56.38 \pm 4.6 \bullet$ & $53.43 \pm 9.5 \bullet$ & $48.9 \pm 12.4$ & $25.3 \pm 4.6$ \\
\hline Gender $(\mathrm{M} / \mathrm{F})$ & $23 / 1$ & $13 / 1$ & $8 / 2$ & $15 / 10$ \\
\hline $\operatorname{ALT}(\mathrm{u} / \mathrm{ml})$ & $67.3 \pm 42.7 \bullet$ & $36.1 \pm 7.5 \bullet *$ & $69.4 \pm 41.8^{*}$ & $22.6 \pm 3.9$ \\
\hline $\operatorname{AST}(\mathrm{u} / \mathrm{ml})$ & $78.5 \pm 31.02 \bullet$ & $53.35 \pm 14.99 \bullet$ & $70.5 \pm 40.14$ & $23.8 \pm 5.3$ \\
\hline Albumin (g/dl) & $3.37 \pm 0.55 \bullet$ & $2.8 \pm 0.36 \bullet$ & $3.5 \pm 1.2$ & $4.49 \pm 0.3$ \\
\hline T.Bilirubin (mg/dl) & $2.06 \pm 1.2$ & $2.7 \pm 0.82^{*}$ & $12.68 \pm 0.97^{*}$ & $0.612 \pm 0.03$ \\
\hline Pt count $\left(\mathrm{x} 10^{9}\right)$ & $81.46 \pm 42.1$ & $85.9 \pm 68.5$ & $114.5 \pm 61.5$ & $218.5 \pm 35.4$ \\
\hline Creatinin (mg/dl) & $0.96 \pm 0.17$ & $0.94 \pm 0.12$ & $0.8 \pm 0.13$ & $0.65 \pm 0.13$ \\
\hline HCV RNA $\left(x 10^{6}\right)$ & $2.45 \pm 2.97 \bullet$ & $0.73 \pm 0.92 \bullet$ & $0.07 \pm 2.4$ & - \\
\hline
\end{tabular}

Values are expressed as mean \pm or number $(\%)$

- The difference was considered significant between HCC and LC as regard to age ( $p=0.038)$, ALT ( $p=0.003)$, AST ( $p=0.017$ ), Albumin ( $p=0.004)$, HGCV RNA ( $\mathrm{p}=0.005)$

*The difference was considered significant between LC and CH patients as regard to ALT ( $p=0.004)$ and T. bilirubin ( $p=0.02$ ).

\#Significant difference was recorded $(\mathrm{p}<0.0001)$ between HI and HCC, LC, CH with all variables. 
Table 2: Serum level of AFP, LDH, GGT, TNF-a in all cases of the study group.

\begin{tabular}{|c|c|c|c|c|}
\hline & HCC $N=24$ & LC N=14 & $\mathrm{CH} \mathrm{N}=10$ & HI N=25 \\
\hline $\begin{array}{c}\text { AFP (ng/ml) } \\
\text { mean } \pm \text { SD } \\
\% \text { of positivity }\end{array}$ & $\begin{array}{c}170.98 \pm 284.0 \bullet * \\
19 / 24(79.2 \%)\end{array}$ & $\begin{array}{l}6.15 \pm 3.39 \\
0 / 14(0 \%)\end{array}$ & $\begin{array}{l}24.9 \pm 61.6^{*} \\
1 / 10(10 \%)\end{array}$ & $\begin{array}{c}5.03 \pm 1.8 \\
0 / 25(0 \%)\end{array}$ \\
\hline $\begin{array}{c}\mathrm{LDH}(\mathrm{u} / \mathrm{l}) \\
\text { mean } \pm \mathrm{SD} \\
\% \text { of positivity }\end{array}$ & $\begin{array}{c}413.2 \pm 84.6^{*} \\
24 / 24(100 \%)\end{array}$ & $\begin{array}{c}320.0 \pm 41.51 \\
12 / 14(85.7 \%)\end{array}$ & $\begin{array}{c}341.6 \pm 114.95^{*} \\
7 / 10(70 \%)\end{array}$ & $\begin{array}{l}217.3 \pm 51.1 \\
6 / 25(24 \%)\end{array}$ \\
\hline $\begin{array}{c}\text { GGT }(\mathrm{u} / \mathrm{l}) \\
\text { mean } \pm \text { SD } \\
\% \text { of positivity }\end{array}$ & $\begin{array}{c}76.3 \pm 75.5 \\
9 / 24(37.5 \%)\end{array}$ & $\begin{array}{l}37.6 \pm 12.3 \\
0 / 14(0 \%)\end{array}$ & $\begin{array}{c}71.6 \pm 81.3 \\
3 / 10(30 \%)\end{array}$ & $\begin{array}{c}23.7 \pm 9.5 \\
1 / 25(4 \%)\end{array}$ \\
\hline $\begin{array}{c}\text { TNF- } \alpha(\mathrm{pg} / \mathrm{ml}) \\
\text { mean } \pm \text { SD } \\
\% \text { of positivity }\end{array}$ & $\begin{array}{c}520.6 \pm 48.4^{*} \\
24 / 24(100 \%)\end{array}$ & $\begin{array}{c}414.3 \pm 43.1+ \\
13 / 14(92.9 \%)\end{array}$ & $\begin{array}{c}315.5 \pm 34.8^{*}+ \\
2 / 10(20 \%)\end{array}$ & $\begin{array}{c}288.8 \pm 25.5 \\
1 / 25(4 \%)\end{array}$ \\
\hline \multicolumn{5}{|c|}{ The difference was considered significant between HCC and LC as regard to AFP (p<0.0001), LDH $(p=0.001), T N F-\alpha(p<0.0001)$} \\
\hline \multicolumn{5}{|c|}{ *The difference was considered significant between HCC and CH as regard to AFP (p=0.003), LDH $(p=0.008)$, TNF- $\alpha(p<0.0001)$} \\
\hline \multicolumn{5}{|c|}{ +The difference was considered significant between LC and CH as regard to TNF- $\alpha(\mathrm{p}<0.0001)$} \\
\hline
\end{tabular}

Laboratory investigation and biochemical markers in HCVinfected patients considered to viral load (data not shown) showed no significant difference with all variables within all groups except in LDH group ( $388.5 \pm 130.56$ vs $271.25 \pm 15.47, \mathrm{p}=0.01$ ). Correlation between TNF- $\alpha$, LDH, GGT and AFP in HCV-infected patients was listed in Table 3. AFP was associated with LDH ( $\mathrm{r}=0.35, \mathrm{p}=0.015)$, TNF- $\alpha$ was associated with LDH ( $r=0.37, p=0.009)$, GGT was

Table 3: Correlation between TNF-a, LDH, GGT and other biochemical markers of liver diseases in HCV-chronic liver disease.

\begin{tabular}{|c|c|c|c|c|c|c|c|}
\hline GGT & 1 & & & & & & \\
\hline $\mathrm{LDH}$ & $\begin{array}{c}0.549^{* *} \\
0.000\end{array}$ & 1 & & & & & \\
\hline AFP & $\begin{array}{l}0.175 \\
0.235\end{array}$ & $\begin{array}{l}0.35^{*} \\
0.015\end{array}$ & 1 & & & & \\
\hline TNF- $\alpha$ & $\begin{array}{c}0.17 \\
0.228\end{array}$ & $\begin{array}{c}0.37^{* *} \\
0.009\end{array}$ & $\begin{array}{l}0.279 \\
0.055\end{array}$ & 1 & & & \\
\hline HCV RNA & $\begin{array}{c}0.03 \\
0.823\end{array}$ & $\begin{array}{l}0.22 \\
0.13\end{array}$ & $\begin{array}{c}0.045 \\
0.76\end{array}$ & $\begin{array}{c}0.061 \\
0.68\end{array}$ & 1 & & \\
\hline ALT & $\begin{array}{c}0.457^{* *} \\
0.001\end{array}$ & $\begin{array}{c}0.336^{*} \\
0.02\end{array}$ & $\begin{array}{l}0.06 \\
0.66\end{array}$ & $\begin{array}{l}0.13 \\
0.38\end{array}$ & $\begin{array}{l}0.163 \\
0.268\end{array}$ & 1 & \\
\hline \multirow[t]{2}{*}{ AST } & $\begin{array}{l}0.34^{*} \\
0.018\end{array}$ & $\begin{array}{c}0.52^{* *} \\
0\end{array}$ & $\begin{array}{l}0.213 \\
0.146\end{array}$ & $\begin{array}{c}22 \\
0.13\end{array}$ & $\begin{array}{l}0.39 * * \\
0.006\end{array}$ & $\begin{array}{c}0.686^{* *} \\
0\end{array}$ & 1 \\
\hline & GGT & $\mathrm{LDH}$ & AFP & TNF- $\alpha$ & HCV RNA & ALT & AST \\
\hline
\end{tabular}

associated with LDH ( $\mathrm{r}=0.549, \mathrm{p}<0.0001)$, ALT $(\mathrm{r}=0.457, \mathrm{p}=0.001)$ and AST ( $r=0.34, p=0.018)$. Therefore, LDH showed significant correlation with AFP, TNF- $\alpha$, GGT (Figure 1) in addition to ALT $(\mathrm{r}=0.336, \mathrm{p}=0.02)$ and AST $(\mathrm{r}=0.52, \mathrm{p}<0.0001)$. LDH $(\mathrm{p}=0.008)$, TNF- $\alpha(\mathrm{p}<0.0001)$ and AFP ( $\mathrm{p}=0.028)$ showed significant prediction for disease progression in HCV chronic liver disease (Figure 2) by linear regression analysis.

Note:

a) ${ }^{* *}$ Correlation is considered significant at the 0.01 level.

b) $\quad{ }^{*}$ Correlation is considered significant at the 0.05 level. 


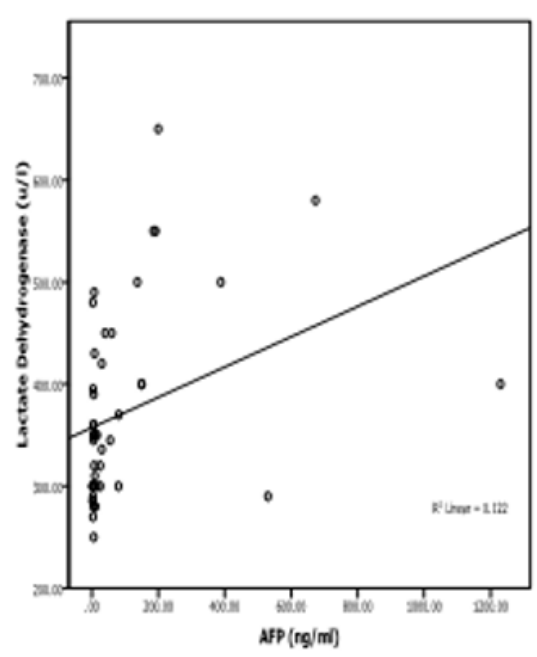

(a)

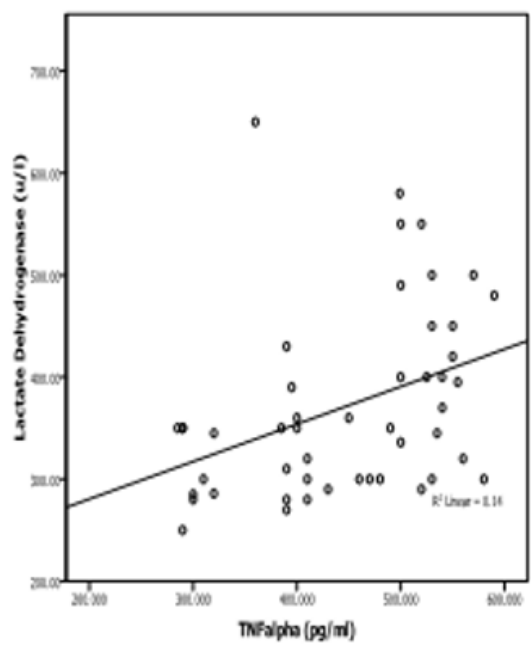

(b)

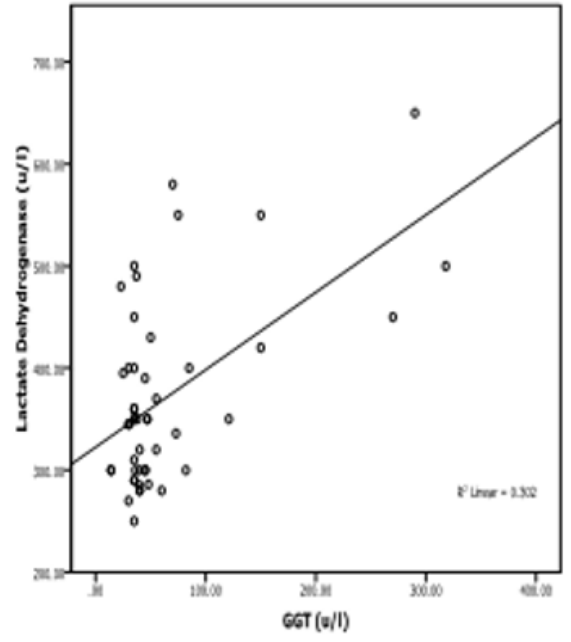

(c)

Figure 1: Correlation between LDH with AFP
a) TNF- $\mathrm{a}$
b) And GGT
c) In patients with $\mathrm{HCV}$ - chronic liver disease.

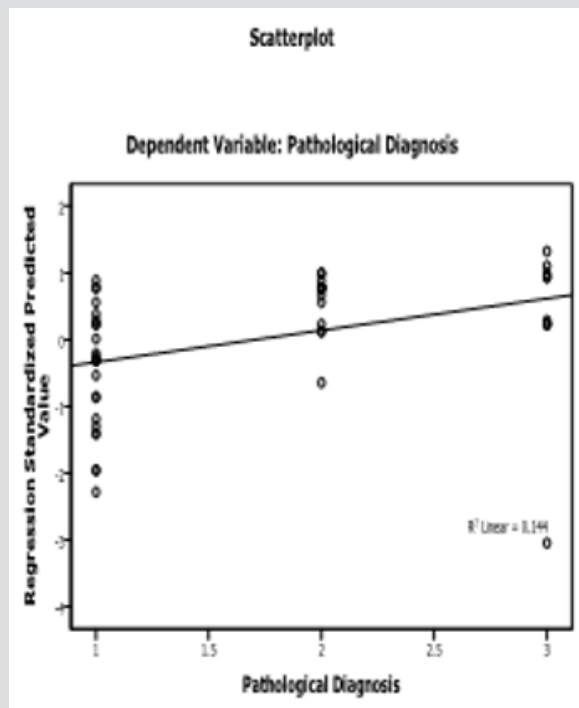

(a)

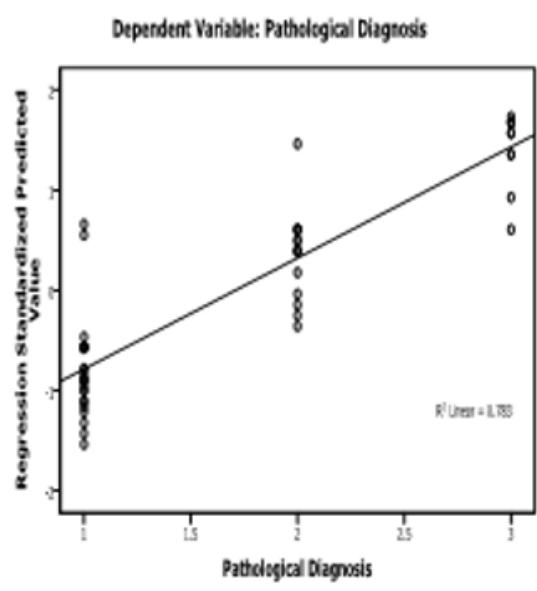

(b)

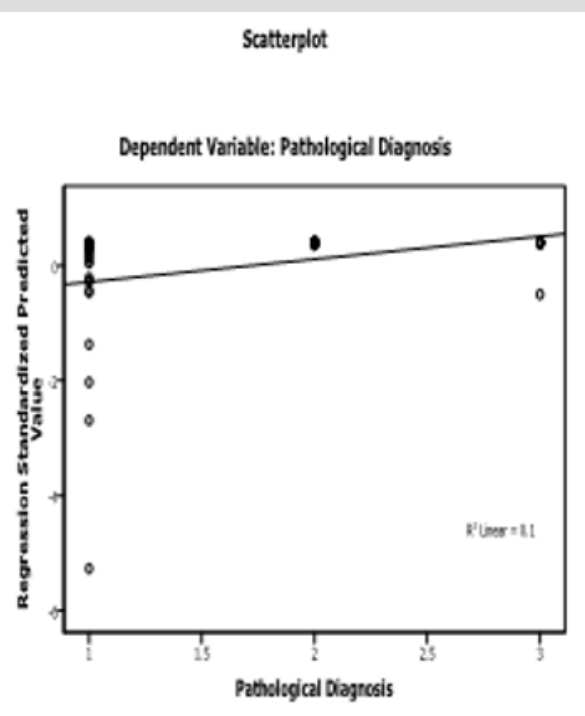

(c)

Figure 2: Scatterplot of LDH
a) TNF-a
b) And AFP
c) With disease progression in patients with $\mathrm{HCV}$-chronic liver disease.

\section{Discussion}

Several serum tumor markers are used currently for the evaluation of tumor progression and prognosis of patients with HCC, including AFP [10]. The diagnostic capacity of AFP depends on its elevation in the serum; concentration of AFP greater than the upper reference limit indicate the presence of HCC but values below this level are less useful because they may also occur in chronic liver disease [11]. In the present study, serum concentration of AFP in HCC group with average value $170.98 \pm 284.0 \mathrm{ng} / \mathrm{ml}$ was considered significant $(\mathrm{p}<0.0001)$ compared to $\mathrm{LC}(6.15 \pm 3.39 \mathrm{ng} / \mathrm{ml})$ and $\mathrm{CH}$ (24.9 $\pm 61.6 \mathrm{ng} / \mathrm{ml}, \mathrm{p}=0.003)$. Positive serum AFP $(>15 \mathrm{ng} / \mathrm{ml})$ was detected in $79.2 \%$ of HCC patients and in only one case of $\mathrm{CH}(10 \%)$ 
but all cases with liver cirrhosis were detected negative for AFP. Therefore, the sensitivity of AFP in HCC patients in current study is comparable to that recorded by Raedle et al. [21] and Gadelhak et al. [11] (69.3\%, 58.46\% respectively). However, this low sensitivity of AFP makes its value limited in the diagnosis and the prognosis of HCC, but it is independent of other predictors [22].

Therefore, to improve the sensitivity of HCC detection by serum markers, various biomarkers are used in combination with AFP.TNF- $\alpha$ plays a central role in the host's immunomodulatory response to infective agents [23] and hepatitis infection is associated with increased transcriptional expression of the TNF- $\alpha$ gene in the liver with high serum levels of TNF- $\alpha$ [24]. Currently, the level of TNF- $\alpha$ was elevated significantly $(\mathrm{p}<0.0001)$ in the sera of HCC patients compared to $\mathrm{LC}$ and $\mathrm{CH}$ and also, elevated in LC than $\mathrm{CH}(\mathrm{p}<0.0001)$. Elevated serum TNF- $\alpha$ level have been observed by other researchers even in patients with mild liver inflammation, indicating that this cytokine could be used as a predictor of liver inflammation [25]. TNF- $\alpha$ level was not correlated with ALT, AST, or viral load in current study and these results are in consistence with other reports, that, serum TNF- $\alpha$ level was not correlated with serum ALT or AST activities neither in HBV nor in HCV infected patients [26].

Such results have also been reported by other authors and it is concluded that, measurement of TNF- $\alpha$ levels reflects liver injury despite normal levels of liver enzymes [27,28]. Increased GGT activity is associated with liver injury and with mortality in the general population but less is known about its association with chronic hepatitis (HCV) outcomes [29]. Among patients with chronic HCV, higher GGT activity has been associated with more severe liver disease in a number of cross sectional studies [30-34]. On contrary, other cross sectional studies provide in conclusive evidence that GGT is associated with liver disease progression [35]. GGT elevation in current study was increased in HCC patients than in LC and $\mathrm{CH}$ but significant association with liver disease progression was not detected suggesting that GGT is not a marker for disease severity.

Patients with elevated GGT had significantly higher serum levels of AST but no association between ALT, viral load and GGT [36]. Also, Silva et al. [32], demonstrated that there is no significant association between increased GGT levels and ALT in logistic regression analysis. In current study, GGT showed significant association with ALT ( $r=0.457, \mathrm{p}=0.001)$ and AST $(r=0.34, p=0.018)$ but there is no significant association with viral load. These results are in agreement with Hwang et al. [37] who demonstrated that, a highly significant correlation was recorded between serum level of ALT and GGT but elevated serum GGT was not correlated with serum HCV RNA titer or HCV genotype. Such results suggest that the histological damage could represent a common origin of the alteration of both enzymes ALT and GGT [38]. LDH is a commonly used serum biomarker, which is easily and cheap to detect and, thus, appropriate for the use in routine clinical practice [19]. In current study, serum concentration of LDH was highly elevated in patients with HCC than in LC ( $\mathrm{p}=0.001)$ and $\mathrm{CH}(\mathrm{p}=0.008)$ but there is no significant difference between $\mathrm{LC}$ and $\mathrm{CH}$. Therefore, elevated LDH is a possible indicator of disease progression [39]. LDH was also correlated positively with liver disease markers ALT ( $r=0336$, $\mathrm{p}=0.02)$ and AST $(\mathrm{r}=0.52, \mathrm{p}<0.0001)$ suggesting that, $\mathrm{LDH}$ is an enzyme that is expressed at higher levels when cells are distressed and damaged. LDH, TNF- $\alpha$, and AFP showed significant prediction for disease progression in HCV infected patients of our study. Therefore, our results concluded that, LDH and TNF- $\alpha$ could be used simultaneously with AFP for the evaluation of chronic inflammation associated with HCV infection leading to HCC development.

\section{References}

1. Siegel RL, Miller KD, Jemal A (2015) Cancer statistics. Cancer J Clin 65(1): 5-29.

2. Singal AG, El Serag HB (2015) Hepatocellular Carcinoma from epidemiology to prevention: Translating knowledge into practice. Clinical gastroenterology and hepatology 13(12): 2140-2151.

3. Chen W, Zheng R, Baade PD, Zhang S, Zeng H, et al. (2016) Cancer statistics in China. Cancer J Clin 66(2): 115-132.

4. Moustafa M, Morsi M, Hussein A, Al Abd E, Abdel Moneim N (2005) Evaluation of Tumor necrosis factor- $\alpha$ (TNF- $\alpha$ ), soluble P-selectin (sPSelectin), gamma-glutamyl transferase (GGT), glutathione S-transferase Pi (GST-Pi) and alpha fetoprotein (AFP) in patients with hepatocellular carcinoma before and during chemotherapy. Turkish Journal of Cancer 35(1): 5-11.

5. Reherman B, Nascimbeni M (2005) Immunology of hepatitis B virus and hepatitis $C$ virus infection. Nat Rev Immunol 5(3): 215-229.

6. Falasca K, Ucciferri C, Dalessandro M, Zingariello P, Mancino P, et al. (2006) Cytokine patterns correlate with liver damage in patients with chronic hepatitis B and C. Ann Clin Lab Sci 36(2): 144-150.

7. Larrubia JR, Benito Martínez S, Miquel Plaza J, Sanz de Villalobos E, González Mateos F, et al. (2009) Cytokines - their pathogenic and therapeutic role in chronic viral hepatitis. Rev Esp Enferm Dig 101(5): 343-351.

8. Camussi G, Albano E, Tetta C, Bussolino F (1991) The molecular action of tumor necrosis factor alpha. Eur J Biochem 202(1): 3-14.

9. Romieu R, Lacabanne V, Kayibanda M, Antoine B, Bennoun M, et al. (1997) Critical stages of tumor growth regulation in transgenic mice harboring a hepatocellular carcinoma revealed by distinct patterns of tumor necrosis factors- $\alpha$ and transforming growth factor- $\beta$ mRNA production. Intl Immunol 9(10): 1405-1413.

10. Toyoda H, Kumada T, Kiriyama S, Sone Y, Tanikawa M, et al. (2006) Prognostic significance of simulataneous measurement of three tumor markers in patients with hepatocellular carcinoma. Clin Gastroenterol Hepatol 4(1): 111-117.

11. Gadelhak NA, Gadelhak SA, Elmorsy DA, Abdelaziz MM, Abbas AT, et al. (2009) Prognostic significance of three hepatitis markers (p53 antibodies, vascular endothelial growth factors and alpha fetoprotein) in patients with hepatocellular carcinoma. Hepato-gastroenterology 56(94-95): 1417-1724.

12. Mauro P, Renze B, Wouter W (2006) Enzymes. In: Tietz text book of clinical chemistry and molecular diagnostics. Carl AB, Edward R, David EB, 4th edition, Elsevier pp. 604-616.

13. Whitfield JB (2001) Gamma glutamyl transferase. Crit Rev Clin Lab Sci 38(4): 263-355.

14. Targher G (2010) Elevated serum gamma-glutamyltransferase activity is associated with increased risk of mortality, incident type 2 diabetes, cardiovascular events, chronic kidney disease and cancer - a narrative review. Clin Chem Lab Med 48(2): 147-157.

15. Haring R, Wallaschofski H, Nauck M, Dorr M, Baumeister SE, et al. (2009) Ultrasonographic hepatic steatosis increases prediction of mortality risk from elevated serum gamma-glutamyl transpeptidase levels. Hepatology 50(5): 1403-1411. 
16. Ruhl CE, Everhart JE (2009) Elevated serum alanine aminotransferase and gamma-glutamyltransferase and mortality in the United States population. Gastroenterology 136(2): 477-485.

17. Markert CL (1963) Lactate Dehydrogenase Isozymes: Dissociation and Recombination of Subunits. Science 140(3573): 1329-1330.

18. Lu X, Kang Y (2010) Hypoxia and hypoxia-inducible factors: master regulators of metastasis. Clinical cancer research 16(24): 5928-5935.

19. Faloppi L, Bianconi M, Memeo R, Casadei Gardini A, Giampieri R, et al. (2016) Lactate Dehydrogenase in Hepatocellular Carcinoma: Something Old, Something New. BioMed research international, 7196280.

20. Li MX, Zhao H, Bi XY, Li ZY, Yao XS, et al. (2016) Lactate dehydrogenase is a prognostic indicator in patients with hepatocellular carcinoma treated by sorafenib: results from the real life practice in HBV endemic area. Oncotarget 7(52): 86630-86647.

21. Raedle J, Oremek G, Rruschnowitsch M, Lorenz M, Roth WK, et al. (1998) Clinical evaluation of autoantibodies to p53 protein in patients with chronic liver disease and hepatocellular carcinoma. Eur J Cancer 34(8): 1198-1203.

22. Farinati F, Marino D, De Giorgio M, Baldan A, Cantarini M, et al. (2006) Diagnostic and prognostic role of $\alpha$-fetoprotein in hepatocellular carcinoma: both or neither? Am J Gastroenterol 101(3): 524-532.

23. Nelson DR, Lim HL, Marousis CG, Fang JWS, Davis GL, et al. (1997) Activation of tumor necrosis factor- $\alpha$ system in chronic hepatitis $C$ virus infection. Digestive Diseases and Sciences 42(12): 2487-2494.

24. Larrea E, Garcia N, Qian C, Civeira MP, Prieto J (1996) Tumor necrosis factor alpha gene expression and the response to interferon in chronic hepatitis C. Hepatol 23(2): 210-217.

25. Moura AS, Carmo RA, Teixeira AL, da Costa Rocha MO (2009) Soluble inflammatory markers as predictors of hepatocellular damage and therapeutic response in chronic hepatitis C. Braz J Infect Dis 13(5): 375382.

26. Mourtzikou A, Alepaki M, Stamouli M, Pouliakis A, Skliris A, et al. (2014) Evaluation of serum levels of IL-6, TNF- $\alpha$, IL-10, IL-2 and IL-4 in patients with chronic hepatitis. Inmunologia 33: 41-50.

27. Jeng JE, Tsaiz JF, Chuang LY, Ho MS, Linz ZY, et al. (2007) Tumor necrosis factor-A 308.2 polymorphism is associated with advanced hepatic fibrosis and higher risk for hepatocellular carcinoma. Neoplasia 9(11): 987-992.

28. Astakhin AV, Levitan BN, Afanasev SS, Vorobev AA, Aleshkin VA, et al (2004) Tumor necrosis factor-alpha and interleukin-4 in the blood sera of chronic hepatitis patients. Zh Mikrobiol Epidemiol Immunobiol 2: 4650 .

\section{ISSN: 2574-1241}

DOI: 10.26717/BJSTR.2019.17.003004

Hoda Mohamed El-Emshaty. Biomed J Sci \& Tech Res

This work is licensed under Creative Commons Attribution 4.0 License

Submission Link: https://biomedres.us/submit-manuscript.php
29. Everhart JE, Wright EC (2013) Association of $\gamma$-Glutamyl Transferase (GGT) Activity with Treatment and Clinical Outcomes in Chronic Hepatitis C (HCV). Hepatology 57(5): 1725-1733.

30. Paolicchi A, Marchi S, Petruccelli S, Ciancia E, Malvaldi G, et al. (2005) Gamma glutamyltransferase in fine-needle liver biopsies of subjects with chronic hepatitis C. J Viral Hepat 12(3): 269-273.

31. Papatheodoridis GV, Chrysanthos N, Sawas S, Sevastianos V, Kafiri G, et al. (2006) Diabetes mellitus in chronic hepatitis B and C: prevalence and potential association with the extent of liver fibrosis. J Viral Hepat 13(5): 303-310.

32. Silva IS, Ferraz ML, Perez RM, Lanzoni VP, Figueiredo VM, et al. (2004) Role of gamma-glutamyl transferase activity in patients with chronic hepatitis C virus infection. J Gastroenterol Hepatol 19(3): 314-318.

33. Valenti L, Rumi M, Galmozzi E, Aghemo A, Del Menico B, et al. (2011) Patatin-like phospholipase domain-containing 3 I148M polymorphism, steatosis, and liver damage in chronic hepatitis C. Hepatology 53(3): 791-799.

34. Vardar R, Vardar E, Demiri S, Sayhan SE, Bayol U, et al. (2009) Is there any non-invasive marker replace the needle liver biopsy predictive for liver fibrosis, in patients with chronic hepatitis? Hepatogastroenterology 56: 1459-1465.

35. Forns X, Ampurdanes S, Sanchez Tapias JM, Guilera M, Sans M, et al. (2001) Long-term follow-up of chronic hepatitis $\mathrm{C}$ in patients diagnosed at a tertiary-care center. J Hepatol 35(2): 265-271.

36. Abdel Aal E, Omar N, Zaghla H, Taha HEA, Ehsan NA, et al. (2007) Role of Gamma Glutamyl Transferase in patients with Chronic Hepatitis C Virus infection. Tanta Medical Journal 35: 339-405.

37. Hwang SJ, Luo JC, Lai CR, Chu CW, Tsay SH, et al. (2000) Clinical, virologic and pathologic significance of elevated serum gamma-glutamyl transpeptidase in patients with chronic hepatitis C. Chung Hua I Hsueh Tsa Chih (Taipei) 63(7): 527-535.

38. Mihm S, Hartmann H, Fayyazi A, Ramadori G (1996) Preferential virological response to interferon-alpha $2 \mathrm{a}$ in patients with chronic hepatitis $C$ infected by virus genotype $3 a$ and exhibiting a low gammaGT/ALT ratio. Dig Dis Sci 41(6): 1256-1264.

39. Brown JEI, Cook RJ, Lipton A, Coleman RE (2012) Serum lactate dehydrogenase is prognostic for survival in patients with bone metastasis from breast cancer: a retrospective analysis in bisphosphonate-treated patients. Clin Cancer Res 18(22): 6348-6355.

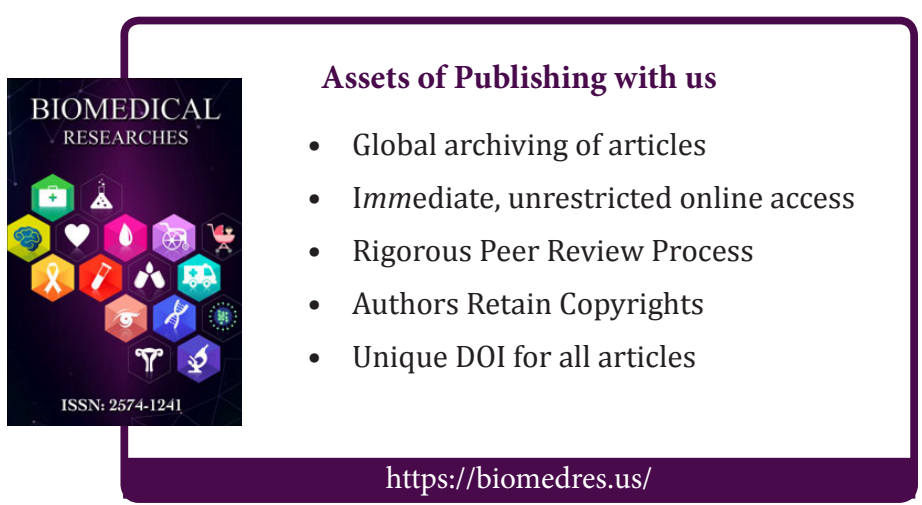

